\title{
Morphological and Physiological Responses of Morus alba Seedlings under Different Light Qualities
}

\author{
Juwei HU, Xin DAI, Guangyu SUN* \\ Northeast Forestry University, College of Life Science, 26 Hexing Road, Harbin, 150040, \\ China; hujuwei1988@aliyun.com;732790596@qq.com;sungy@vip.sina.com (*correspondingauthor)
}

\begin{abstract}
Light quality can influence the photosynthetic characteristics, morphology and physiological processes of plants. To investigate the effects of different light qualities (white light, W; red light, R; blue light, B; mixture of red and blue light, RB) of light emitting diodes (LEDs) and white cold fluorescent lamp on the growth and morphology of fruiting mulberry plants (Morus alba L. cv. 'Longsang No.1'), fruiting mulberry plants were grown under different light qualities: W, R, B and RB of the same photosynthetic photo flux density (PPFD; $100 \mu \mathrm{mol} \mathrm{m}^{-2} \mathrm{~s}^{-1}$ ) for $20 \mathrm{~d}$. Our results showed that stem length and leaf area of plants grown under $\mathrm{R}$ were the highest. However, stem length and leaf area of plants grown under $\mathrm{B}$ were lowest. Dry weights (DW), leaf mass per area (LMA), chlorophyll a/b ratio, soluble protein content, sucrose and starch content, and total leaf nitrogen $(\mathrm{N})$ content of plants grown under $\mathrm{R}$ were the lowest. Net photosynthetic rate $(\mathrm{Pn})$, stomatal conductance (gs), and actual photochemical efficiency of PSII (ФPSII) of plants grown under RB were similar to plants grown under W. Net photosynthetic rate $(\mathrm{Pn})$ and $\Phi$ PSII of plants grown under $\mathrm{R}$ and $\mathrm{B}$ were lower than plants grown under $\mathrm{W}$ and $\mathrm{RB}$. Antioxidant enzymes activity of plants grown under R, RB and $B$ were higher than plants grown under $W$. The number of leaf stomata, leaf thickness, palisade tissue length and spongy tissue length were the lowest in plants grown under $R$. The number of leaf stomata, leaf thickness and palisade tissue length of plants grown under RB and B were higher than plants grown under R. The results of this study indicate that a certain ratio of mixed red and blue LEDs light can reduce adverse effects of monochromatic red and blue LEDs light on fruiting mulberry growth and development.
\end{abstract}

Keywords: chlorophyll fluorescence, fruiting mulberry (Morus alba L.), leaf anatomical structure, light quality, photosynthetic characteristics

\section{Introduction}

Light is not only a source of energy for plant photosynthesis, but also an important environmental factor affecting plant growth and development (Huché-Thélier et al., 2016). Alterations in light quality (light spectra) can impose enormous effects on plant physiological processes, morphogenesis, growth and development; however, the effects vary between plant species (Demotes-Mainard et al., 2016). Compared to other spectral regions, red light and blue light can be absorbed more effectively by chlorophylls (Inada, 1976; Fankhauser and Chory, 1997). In several plant species, blue light can promote stomatal opening, which facilitates the enhancement of plant photosynthetic capacity along with the increase of dry matter production (Goins et al., 1997; Zeiger et al., 2002; Hernández and Kubota, 2016). Red light induces the outflow of $\mathrm{K}^{+}$and solutes from guard cells and results in stomatal closure (Zeiger, 1990; Chen et al., 2004). Many studies have shown that blue light can regulate the formation of chlorophyll and plants grown under blue light had a relatively higher chlorophyll a/b ratio, few Light-Harvesting Complexes and higher Rubisco activity (Eskins et al., 1991; Matsuda et al., 2004; Wang et al., 2009). Plants grown under red light had a lower chlorophyll $\mathrm{a} / \mathrm{b}$ ratio and biomass than plants grown under white light or mixed red and blue light-emitting diodes (LEDs) (Milivojevic and Tyszkiewicz, 1992; Brown et al., 1995; Gions et al., 1997). Blue light can inhibit the growth of internodes, cell expansion and/or division (Appelgren, 1991; Folta et al., 2003; Dougher and Bugbee, 2004). Blue light can also inhibit leaf unfolding and hypocotyl elongation (Dougher and Bugbee, 2001; Ahmad et al., 2002). In contrast, red light promotes leaf unfolding and hypocotyl elongation (Johkan et al., 2010; Park and Kim, 2010). Researchers found that compared with monochromatic red light, monochromatic blue light could also promote stem elongation (Fukuda et al., 2009). With a relatively lower photosynthetic photon flux 
density (PPFD; $100 \mu \mathrm{mol} \mathrm{m} \mathrm{m}^{-2} \mathrm{~s}^{-1}$ ), blue light can facilitate plant leaf morphology and photosynthesis to present 'sun type' characteristics (Hogewoning et al., 2010b; Terfa et al., 2013). In both limited light and saturated light conditions, rice plants (Oryza sativa L.) grown under mixed red and blue LEDs light had a higher net photosynthetic rate $(\mathrm{Pn})$ than rice plants grown under monochromatic red LEDs light (Matsuda et al., 2004). A previous study also showed that plants grown under monochromatic red or blue light had remarkably higher antioxidant enzymes activity than those grown under white light (Sebastian and Prasad, 2014). Cucumber plants (Cucumis sativus L.) grown under red LEDs alone had leaves with lower maximum photochemical efficiency of PSII $(\mathrm{Fv} / \mathrm{Fm})$, photosynthetic capacity and leaf mass per area (LMA), while these effects were not presented in plants grown under mixed red and blue LEDs (Hogewoning et al., 2010b). The studies mentioned above indicated that red light, blue light and a mixture of red and blue light can affect the photosynthesis, morphology, and physiological characteristics of plants.

Fruiting mulberry is a general designation for mulberry varieties that bear fruits with a high economic or medicinal value (Ercisli and Orhan, 2007). In northern China, the conventional planting method for fruiting mulberry is mainly dominated by field planting, and with the rapid development of agriculture, a new nursery cultivation method of pre-cultivating seedlings in greenhouses was adopted to produce high-quality fruiting mulberry seedlings. However, in greenhouses the problem of limited light, such as short daylight time and lack of sunlight in late autumn, winter, and spring, leads to abnormal plant growth and thus impacts fruit yield and quality (Hogewoning and Harbinson, 2006). Hence, selecting effective artificial lighting or taking appropriate measures for supplementing light is important for the development of facility cultivation (Hogewoning and Harbinson, 2006). Artificial light sources used in controlled environment have mainly been fluorescent lamps, high pressure metal halide lamps, gas discharge lamps, etc., the spectra of these lamps differs significantly from solar radiation spectra, and thus they greatly influence plant growth (Hogewoning et al., 2010a). Currently, the light-emitting diodes (LEDs) is a better light source for plants (Hogewoning and Harbinson, 2006; Mass et al., 2007; Massa et al., 2008). Compared with broadband spectra light sources, the light spectrum emitted by LEDs falls only into a narrow band; therefore, LEDs provide a better way of studying the effects of different light quality on the growth and photosynthesis of plants (Hogewoning and Harbinson, 2006). However, the effects of red and blue LEDs on morphology, photosynthesis, and physiological characteristics of fruiting mulberry plants have not been reported.

The objective of the study is to evaluate the effects of red LEDs, a mixture of red and blue LEDs, and blue LEDs on morphological and physiological parameters of fruiting mulberry plants. These results can provide basic data for the regulation of light conditions during cultivation of fruiting mulberry seedlings in greenhouses.

\section{Materials and Methods}

\section{Plant materials and light treatments}

This study used one-year-old fruiting mulberry seedlings (Morus alba L. cv. 'Longsang No.1') with branches, leaves and roots removed; only the main stem and root with a length of 2 $\mathrm{cm}$ remained. The seedlings were then individually transplanted into pots with a diameter of $8 \mathrm{~cm}$ and height of 10 $\mathrm{cm}$, which were filled with a mixture of soil to sand $(4: 1, \mathrm{~V} / \mathrm{V})$. For each plant, the most robust branch was kept and other branches were removed by way of bud picking at the beginning of sprouting. After transplanting, all plants were placed in a growth chamber, light was provided by white cold fluorescent lamp with a photosynthetic photon flux density (PPFD) of $100 \mu \mathrm{mol} \mathrm{m} \mathrm{m}^{-1}$, seedlings were cultivated under white cold fluorescent lamp for two weeks. Ambient conditions were controlled as follows: the photoperiod was $14 \mathrm{~h} / 10 \mathrm{~h}$ (day/night), the daytime temperature was $28 \pm 2{ }^{\circ} \mathrm{C}$, the night temperature was $23 \pm 2{ }^{\circ} \mathrm{C}$, the relative humidity was $60 \%$ $65 \%$, and plants were watered every $3 \mathrm{~d}$.

As a multi-wavelength white light control (W), some seedlings were still kept under white cold fluorescent lamp ranging from 410 to $700 \mathrm{~nm}$. The other plants were moved into light-emitting diode (LED) cabinets and given exposure to red light $(\mathrm{R})$, a mixture of red and blue light $(\mathrm{RB})$ and blue light (B). $\mathrm{R}$ was produced by red LEDs, $\mathrm{B}$ was produceed by blue LEDs, and RB was produced by a mixture of red and blue LEDs (red LED : blue LED = 5:1). The LED light source was an array $(20 \times 30 \mathrm{~cm})$ composed of 300 LEDs. The peak emission for the red LED and blue LED were $660 \mathrm{~nm}$ and 465 $\mathrm{nm}$ respectively. All light sources were designed by Lvying Photoelectricity Co., China. The spectrum and photosynthetic photon flux density (PPFD) of different light sources were measured using a spectrometer (OPT-2000, ABDPE CO., Beijing, China) and a quantum sensor (LI-250A, Licor, USA). By adjusting the distance from the light source to the top of the plants, the light intensity of each light quality treatment was kept at $100 \mu \mathrm{mol} \mathrm{m} \mathrm{m}^{-1}$. Seedlings were cultured under different light qualities for $20 \mathrm{~d}$ and then the parameters were measured.

\section{Growthparametermeasurements}

Stem length was measured from the base of stem to the top of plant. Leaf area was measured with a leaf area meter (LI3000C, Licor, USA). The plant stems and leaves were dried to a constant weight at $80^{\circ} \mathrm{C}$ and an electronic balance was used to measure dry weights (DW). Leaf mass per area (LMA) was calculated based on the leaf area and dry weight of the second fully expanded leaf from the top of the plant.

\section{Measurements of chlorophyll, soluble protein, carbohydrate and total leaf $N$ content}

Six leaf discs (each $1.5 \mathrm{~cm}^{2}$ ) were cut randomly from each fresh leaf, avoiding the leaf margins and main veins, and then immersed into $15 \mathrm{~mL}$ of $80 \%$ acetone. The absorbance of the extract was measured with a spectrophotometer (TU1810, Persee Co.,China) after the leaf discs turned white, and the chlorophyll content was calculated using the method described by Arnon (1949). Soluble protein content was measured with the method described by Bradford (1976). Leaves $(0.5 \mathrm{~g}, \mathrm{DW})$ were ground with $25 \mathrm{~mL}$ of $80 \%(\mathrm{~V} / \mathrm{V})$ ethanol to extract soluble sugar, then this mixture was centrifuged at $3500 \mathrm{~g}$ for $10 \mathrm{~min}$, and the supernatant was obtained for the measurement of sucrose content. Twenty-five $\mathrm{mL} 2 \%(\mathrm{~V} / \mathrm{V}) \mathrm{HCl}$ was added to the precipitate and it was boiled for $3.5 \mathrm{~h}$. Then the mixture was centrifuged again at $4000 \mathrm{~g}$ for $10 \mathrm{~min}$ after cooling. The supernatant was used for the determination of starch content. Sucrose and starch 
384

contents were determined according to the methods mentioned in previous studies (Buysse and Merckx, 1993; Martin et al., 2010). Additionally, 15 leaf discs (each $1.5 \mathrm{~cm}^{2}$ ) were cut from each fresh leaf, dried at $80{ }^{\circ} \mathrm{C}$ for $12 \mathrm{~h}$ and weighed, then the total leaf $\mathrm{N}$ content was measured using an elemental analyzer (Vario MAX CN, Elementar, Germany).

\section{Measurements of gas exchange parameters and chlorophyll fluorescenceparameters}

The net photosynthetic rate $(\mathrm{Pn})$ and stomatal conductance (gs) of the second fully expanded leaves from the top of the plants were measured with a LI-6400XT portable photosynthetic instruments (Licor, USA). The leaf chamber temperature was controlled at $28 \pm 1^{\circ} \mathrm{C}$, relative humidity was $65 \%$, the external $\mathrm{CO}_{2}$ concentration was $400 \mu \mathrm{mol} \mathrm{mol}^{-1}$, and the light sources during measurements of gas exchange parameters of each treatment was the same as during cultivation, with a photon flux density (PFD) being $100 \mu \mathrm{mol}$ $\mathrm{m}^{-2} \mathrm{~s}^{-1}$. The same leaf for measuring gas exchange parameters was used to measure chlorophyll fluorescence parameters by utilizing an FMS-2 Chlorophyll Fluorometer (Hansatech, UK). Prior to the measurements, the plants were kept in the dark for $30 \mathrm{~min}$. Measurements and calculations of the maximum photochemical efficiency of PSII $(\mathrm{Fv} / \mathrm{Fm})$, the actual photochemical efficiency of PSII (ФPSII), the efficiency of excitation energy capture by open PSII reaction centres $\left(\mathrm{Fv}^{\prime} / \mathrm{Fm}^{\prime}\right)$, and non-photochemical quenching (NPQ) were conducted according to methods described by Wingler $e t a l$. (2004).

\section{Measurement of antioxidant enzymes activity}

Superoxide dismutase (SOD) activity was measured with the nitro-blue tetrazolium (NBT) light reduction method (Giannopolitis and Ries, 1977). Peroxidase (POD) activity was investigated by measuring the absorbance of the POD catalytic product of guaiacol at $470 \mathrm{~nm}$ in the presence of hydrogen peroxide $\left(\mathrm{H}_{2} \mathrm{O}_{2}\right)$ (Maehly and Chance, 1954). Catalase (CAT) activity was determined by changing rate of the absorbance of $\mathrm{H}_{2} \mathrm{O}_{2}$ at $240 \mathrm{~nm}$ (Aebi, 1984). Malondialdehyde (MDA) content was determined by measuring the absorbance of the product from the reaction of MDA with trichloroacetic acid solution containing $0.5 \%(\mathrm{~W} / \mathrm{V})$ of 2-thiobarbituric acid $(\mathrm{TAB})$ at $532 \mathrm{~nm}$ (Stewart and Bewley, 1980).

\section{Analysis of leaf microstructure}

The samples were taken from the same leaves that were used to measure gas exchange parameters, and the samples were used for observation by scanning electron microscopy (SEM) and transmission electron microscopy (TEM). SEM was used for observing the distribution of stomata and epidermal cell morphology, and TEM was used for observing anatomical characteristics of the leaf cross sections and chloroplast ultrastructures. For the SEM observation, samples (each $1 \times 2$ $\mathrm{mm}$ ) were taken from both sides of the main leaf veins and samples were immediately put into a solution consistitng of $1 \%$ $(\mathrm{W} / \mathrm{V})$ glutaraldehyde in $0.1 \mathrm{~mol} \mathrm{~L}^{-1}$ phosphate buffer $(\mathrm{pH}$ 6.8). Samples were infiltrated under a mild vacuum, and then fixed in a solution consistitng of $4 \%(\mathrm{~W} / \mathrm{V})$ glutaraldehyde in $0.1 \mathrm{~mol} \mathrm{~L}^{-1}$ phosphate buffer $(\mathrm{pH} 6.8)$ at $4{ }^{\circ} \mathrm{C}$ for $3 \mathrm{~h}$. Fixed samples were carefully rinsed with $0.1 \mathrm{~mol} \mathrm{~L}^{-1}$ phosphate buffer and then samples were dehydrated with a graded acetone series for $30 \mathrm{~min}$ for each gradient. Then samples were dehydrated three times wtih pure acetone for $30 \mathrm{~min}$ for each dehydration, dried at a $\mathrm{CO}_{2}$ critical point and sprayed with gold for SEM (Hitachi S-4800, Japan) observation. For TEM observation, the samples (each $1 \times 1 \mathrm{~mm}$ ) were collected from both sides of the main veins and immediately put into a solution consistitng of $1 \%(\mathrm{~W} / \mathrm{V})$ glutaraldehyde in $0.1 \mathrm{~mol} \mathrm{~L}^{-1}$ phosphate buffer (pH 6.8). Samples were infiltrated for about $5 \mathrm{~min}$. After the samples sunk, they were transferred to a solution consistitng of $4 \%(\mathrm{~W} / \mathrm{V})$ glutaraldehyde in $0.1 \mathrm{~mol} \mathrm{~L}^{-1}$ phosphate buffer $(\mathrm{pH}$ 6.8) and fixed at $4{ }^{\circ} \mathrm{C}$ for $3 \mathrm{~h}$, then fully rinsed four times with $0.1 \mathrm{~mol} \mathrm{~L}^{-1}$ phosphate buffer for $30 \mathrm{~min}$ for each rinse. Samples were fixed with $1 \%(\mathrm{~W} / \mathrm{V})$ osmium tetroxide in $0.1 \mathrm{~mol} \mathrm{~L}^{-1}$ phosphate buffer ( $\mathrm{pH}$ 6.8) for $2 \mathrm{~h}$, then rinsed again with 0.1 mol L ${ }^{-1}$ phosphate buffer to wash away the extra fixing solution. After dehydration with a graded acetone series, samples were permeated and embedded in a series of mixtures of pure acetone and epoxy resin with different ratios, then embedded using pure epoxy resin. After embedding, the samples were cut into ultrathin sections. The cross sections were stained with aqueous uranyl acetate and lead citrate before being observed by TEM (Hitachi-7650, Japan). Cross sections of fruiting mulberry leaves were uesd to measure leaf thickness, lengths of palisade tissue and spongy tissue.

\section{Statistical analysis}

All measurements were independently replicated three times or five times. Data were analyzed by one-way ANOVA, and differences between means were tested using a least significance difference (LSD) test at a significance level of 5\% (p $<0.05$ ).

\section{Results}

\section{Effects of light quality on plant growth}

Treatments of different light qualities had significant impacts on the growth and morphological characteristics of fruiting mulberry plants (Table 1). Plants under R showed the highest stem length and average leaf area, followed by plants under $\mathrm{W}$ and $\mathrm{RB}$. The shortest stem length and smallest average leaf area occurred in B treated plants. Plants grown under $\mathrm{W}$ showed significantly higher dry weights (DW) of stems and leaves than other treatments, and plants grown under B had the lowest DW of stems and leaves. The highest leaf mass per unit leaf area (LMA) occurred in plants grown under $\mathrm{B}$ and it was significantly higher compared with other light quality treatments, and the lowest occurred in plants under $R$.

\section{Effects of light quality on biochemical parameters}

As shown in Table 2, chlorophyll content was the highest in plants under $\mathrm{W}$ and significantly higher than plants grown under R, but showed no significant difference with plants grown under $\mathrm{RB}$ and $\mathrm{B}$. The chlorophyll $\mathrm{a} / \mathrm{b}$ ratio of plants under RB and $\mathrm{B}$ had no significant difference with that of plants under $\mathrm{W}$, but the chlorophyll $\mathrm{a} / \mathrm{b}$ ratio of plants grown under $\mathrm{R}$ was significantly lower than plants grown under $\mathrm{W}$. The plants grown under $\mathrm{B}$ showed the highest soluble protein content and total leaf $\mathrm{N}$ content, followed by plants grown under $\mathrm{W}$ and $\mathrm{RB}$, and the lowest occurred in plants grown under R. Sucrose and starch content for plants under B were significantly higher than other light treatments, and the lowest 
Table 1. Effects of light quality on morphology and growth of fruiting mulberry plants

\begin{tabular}{ccccc}
\hline Light treatments & Stem length $(\mathrm{cm})$ & Average leaf area $\left(\mathrm{cm}^{2}\right)$ & Stem dry weight $(\mathrm{g})$ & $\begin{array}{c}\text { Leaf dry weight }(\mathrm{g}) \\
\text { Leaf mass per unit leaf } \\
\text { area }\left(\mathrm{g} \mathrm{m} \mathrm{m}^{-2}\right)\end{array}$ \\
\hline $\mathrm{W}$ & $29.33 \pm 0.67 \mathrm{~b}$ & $49.26 \pm 2.07 \mathrm{a}$ & $0.80 \pm 0.03 \mathrm{a}$ & $1.10 \pm 0.064 \mathrm{a}$ \\
$\mathrm{R}$ & $33.34 \pm 0.33 \mathrm{a}$ & $55.35 \pm 2.84 \mathrm{a}$ & $0.31 \pm 0.03 \mathrm{c}$ & $0.68 \pm 0.001 \mathrm{c}$ \\
$\mathrm{RB}$ & $27.00 \pm 0.58 \mathrm{c}$ & $39.78 \pm 1.96 \mathrm{~b}$ & $0.45 \pm 0.010 \mathrm{~b}$ & $0.93 \pm 0.005 \mathrm{~b}$ \\
\hline B & $18.00 \pm 0.58 \mathrm{~d}$ & $22.89 \pm 2.30 \mathrm{c}$ & $0.18 \pm 0.012 \mathrm{~d}$ & $0.55 \pm 0.049 \mathrm{c}$ \\
\hline
\end{tabular}

$\mathrm{R}$, red light; RB, a mixture of red and blue light (red LED : blue LED = 5:1); B, blue light.

Table 2. Effects of light quality on biochemical parameters of fruiting mulberry leaves

\begin{tabular}{|c|c|c|c|c|c|c|}
\hline $\begin{array}{l}\text { Light } \\
\text { treatments }\end{array}$ & $\begin{array}{c}\text { Chlorophyll } \\
\text { content }\left(\mathrm{g} \mathrm{m}^{-2}\right)\end{array}$ & $\mathrm{Chl} a / b$ ratio & $\begin{array}{l}\text { Soluble protein } \\
\text { content }\left(\mathrm{mg} \mathrm{g}^{-1}\right)\end{array}$ & $\begin{array}{l}\text { Sucrose content } \\
\left(\mathrm{mg} \mathrm{g}^{-1}\right)\end{array}$ & $\begin{array}{l}\text { Starch content } \\
\left(\mathrm{mg} \mathrm{g}^{-1}\right)\end{array}$ & $\begin{array}{c}\text { Total leaf } \mathrm{N} \\
\text { content }\left(\mathrm{g} \mathrm{m}^{-2}\right)\end{array}$ \\
\hline W & $0.34 \pm 0.001 \mathrm{a}$ & $3.23 \pm 0.08 \mathrm{a}$ & $8.22 \pm 0.46 b$ & $7.91 \pm 0.67 b$ & $6.94 \pm 0.76 c$ & $0.63 \pm 0.06 b$ \\
\hline $\mathrm{R}$ & $0.28 \pm 0.011 b$ & $2.79 \pm 0.10 \mathrm{~b}$ & $5.03 \pm 0.39 c$ & $5.07 \pm 0.52 c$ & $12.89 \pm 0.89 b$ & $0.47 \pm 0.04 c$ \\
\hline $\mathrm{RB}$ & $0.33 \pm 0.004 \mathrm{a}$ & $3.18 \pm 0.07 \mathrm{a}$ & $6.79 \pm 0.43 b c$ & $9.90 \pm 0.69 b$ & $13.68 \pm 0.63 b$ & $0.59 \pm 0.03 b$ \\
\hline B & $0.33 \pm 0.016 \mathrm{a}$ & $3.30 \pm 0.13 \mathrm{a}$ & $14.98 \pm 1.64 \mathrm{a}$ & $16.13 \pm 0.58 \mathrm{a}$ & $22.42 \pm 0.38 \mathrm{a}$ & $0.87 \pm 0.03 a$ \\
\hline
\end{tabular}

Note: Different letters within a column indicate significant differences at the level of $5 \%$ (LSD test, $\mathrm{p}<0.05)$. The values represent means \pm SE $(\mathrm{n}=3$ ). W, white light; R, red light; RB, a mixture of red and blue light (red LED : blue LED = $5: 1$ ); B, blue light.

sucrose and starch content appeared in plants grown under $\mathrm{R}$ and $\mathrm{W}$, respectively.

\section{Effects of light quality on gas exchange}

Light quality significantly affected the photosynthesis characteristics of leaves (Fig. 1). Compared with plants grown under $\mathrm{W}$, the Pn under R and B decreased significantly, and the lowest Pn occurred in R-grown plants. There was no significant difference between Pn of RB-grown plants and Wgrown plants (Fig. 1A). Meanwhile, the stomatal conductance (gs) for plants under B was significantly higher than other treatments, while the gs under $\mathrm{R}$ treatment was significantly lower compared with other treatments. There was no significant difference between gs for plants under $\mathrm{W}$ and $\mathrm{RB}$ (Fig. 1B).

\section{Effects of light quality on chlorophyll fluorescence}

As shown in Fig. 2A, compared with the maximum photochemical efficiency of PSII (Fv/Fm) under W, RB had no significant effect on $\mathrm{Fv} / \mathrm{Fm}$. The $\mathrm{Fv} / \mathrm{Fm}$ of plants under $\mathrm{R}$ and $\mathrm{B}$ decreased significantly and the greatest decrease occurred in plants treated with $R$. The effect of light quality on the actual photochemical efficiency of PSII (ФPSII) was similar to the results of Fv/Fm mentioned above (Fig. 2B). Compared with W-grown plants, the efficiency of excitation energy capture by open PSII reaction centres $\left(\mathrm{Fv}^{\prime} / \mathrm{Fm}^{\prime}\right)$ for plants grown under $\mathrm{R}, \mathrm{RB}$ and $\mathrm{B}$ decreased significantly. Plants grown under $\mathrm{R}$ had the lowest $\mathrm{Fv}^{\prime} / \mathrm{Fm}^{\prime}$, and $\mathrm{Fv}^{\prime} / \mathrm{Fm}^{\prime}$ for plants grown under $\mathrm{RB}$ was significantly higher than plants grown under $\mathrm{R}$ and $\mathrm{B}$ (Fig. 2C). The non-photochemical quenching (NPQ) for plants grown under $\mathrm{R}$ was significantly higher than that of plants grown under $\mathrm{W}, \mathrm{RB}$ and $\mathrm{B}$. Non-photochemical quenching (NPQ) for plants grown under $\mathrm{RB}$ and $\mathrm{B}$ was significantly higher than plants grown under W (Fig. 2D).

\section{Effects of light quality on leaf antioxidant enzymes activity}

Superoxide dismutase (SOD), peroxidase (pod) and catalase (cat) are important constituents of the reactive oxygen scavenging system in plants, and different light quality had significant effects on the activities of SOD, pod and cat (Fig. $3 \mathrm{~A}, 3 \mathrm{~B}$ and $3 \mathrm{C}$ ). Superoxide dismutase (SOD), pod and cat activities for plants grown under $\mathrm{R}, \mathrm{RB}$ and $\mathrm{B}$ were significantly

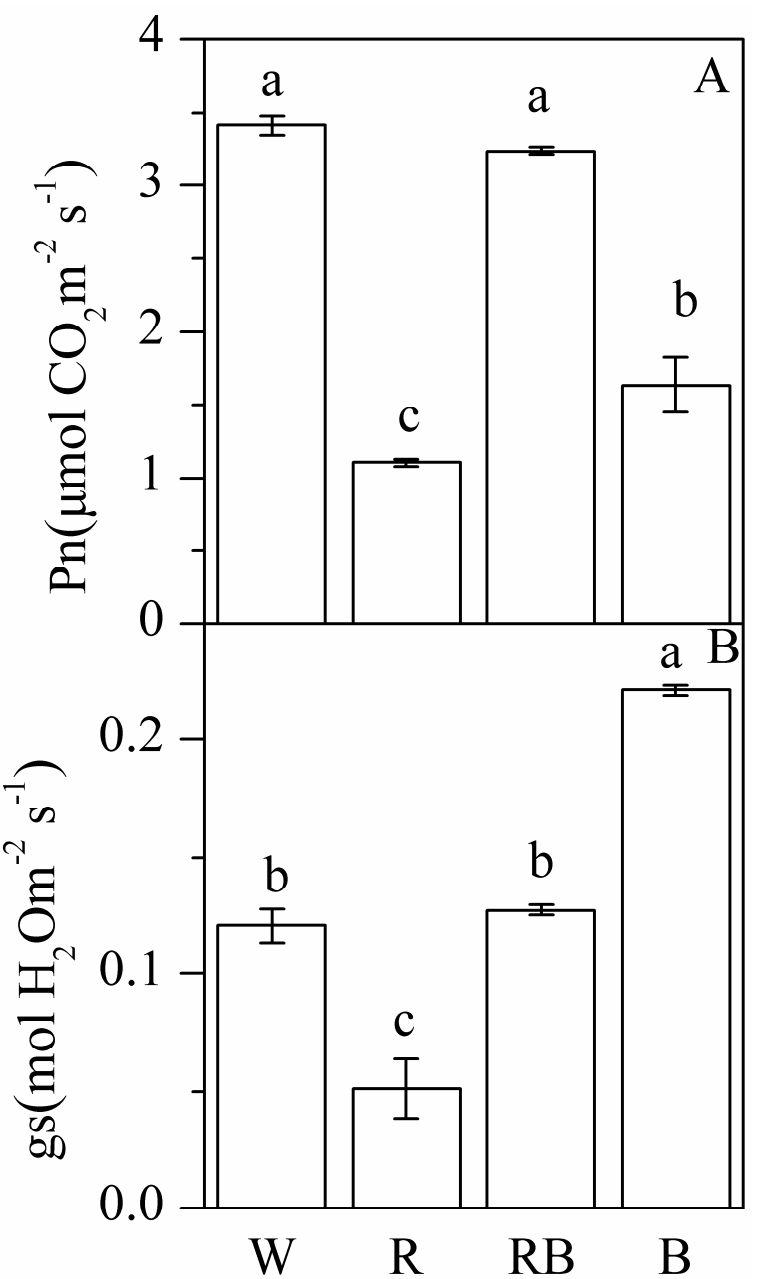

Fig. 1. Effects of light quality on net photosynthetic rate (Pn) (A) and stomatal conductance (gs) (B) of fruiting mulberry leaves. W, white light; $\mathrm{R}$, red light; $\mathrm{RB}$, a mixture of red and blue light (red LED : blue LED = 5 : 1); B, blue light. Different letters indicate significant differences at the level of 5\% (LSD test, $\mathrm{p}<0.05$ ). The values represent means $\pm \mathrm{SE}(\mathrm{n}=3)$ 


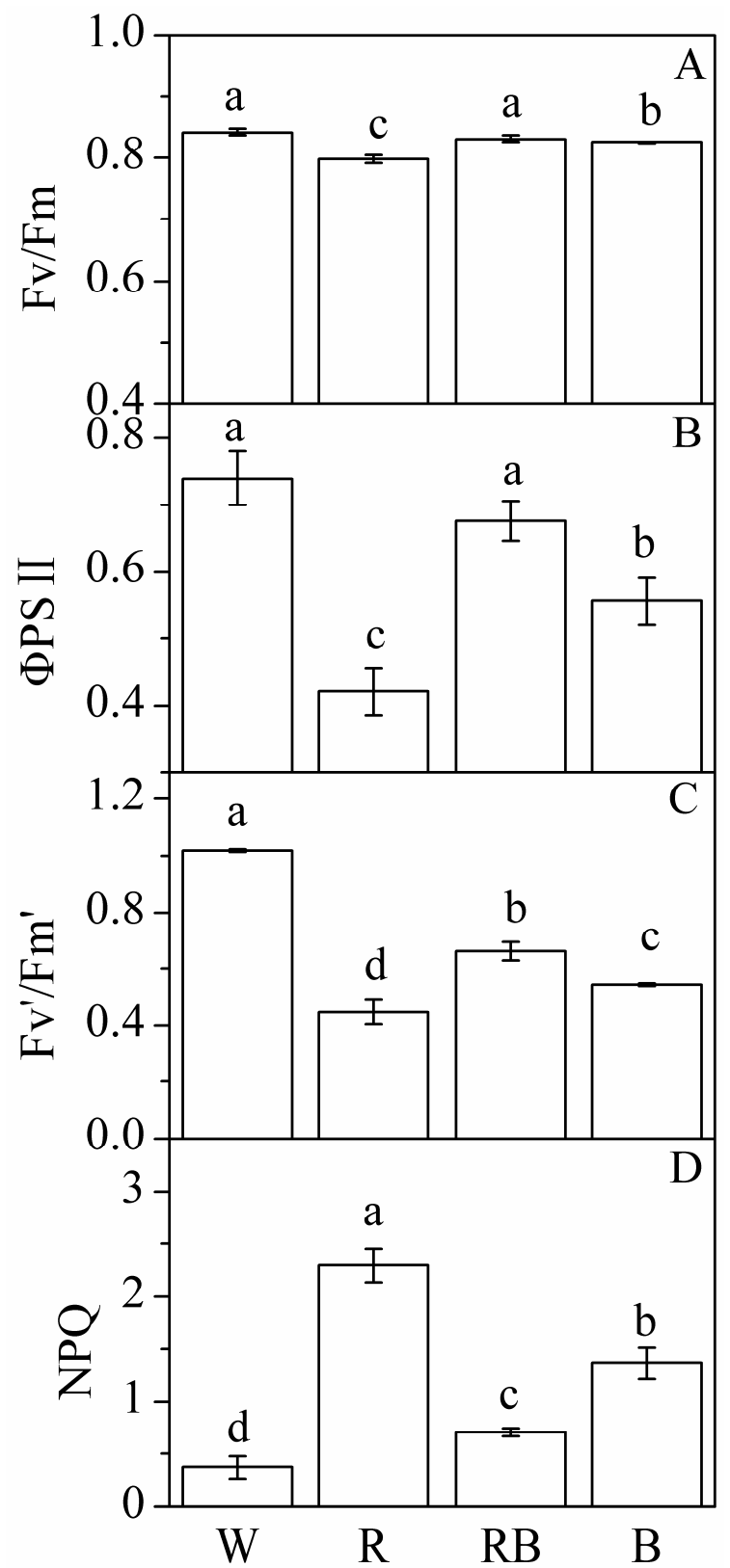

Fig. 2. Effects of light quality on chlorophyll fluorescence parameters of fruiting mulberry leaves. The maximum photochemical efficiency of PSII (Fv/Fm) (A), the actual photochemical efficiency of PSII (ФPSII) (B), the efficiency of excitation energy capture by open PSII reaction centres $\left(\mathrm{Fv}^{\prime} / \mathrm{Fm}^{\prime}\right)(\mathrm{C})$, and non-photochemical quenching (NPQ) (D).W, white light; R, red light; RB, a mixture of red and blue light (red LED : blue LED = 5:1); B, blue light. Different letters indicate significant differences at the level of $5 \%$ (LSD test, $\mathrm{p}<0.05)$. The values represent means \pm SE $(\mathrm{n}=$ 3)

higher compared with plants grown under W. In addition, the activities of SOD, pod and cat were the highest in plants grown under B (Fig. 3A, 3B and 3C). The malondialdehyde (MDA) content of leaves grown under $\mathrm{R}, \mathrm{RB}$ and $\mathrm{B}$ was significantly lower than leaves grown under W (Fig. 3D).

\section{Effects of light quality on leaf microstructure}

Light quality affected the morphology of the abaxial epidermal cells. Compared with plants treated with $\mathrm{W}$, the abaxial epidermal cells were relatively long and narrow under $\mathrm{R}$ treatment, while the abaxial epidermal cells under $\mathrm{B}$ were more regular (Fig. 4A, 4B and 4D). Also, as shown in the Fig. 4A, 4B and $4 \mathrm{D}$, compared with leaves grown under $\mathrm{W}$, the number of stomata distributed in the abaxial epidermis under $\mathrm{R}$ was the lowest, yet under B, more stomata were observed. The number of stomata in the abaxial epidermis under RB had no significant difference with that of the abaxial epidermis under W (Fig. 4C).

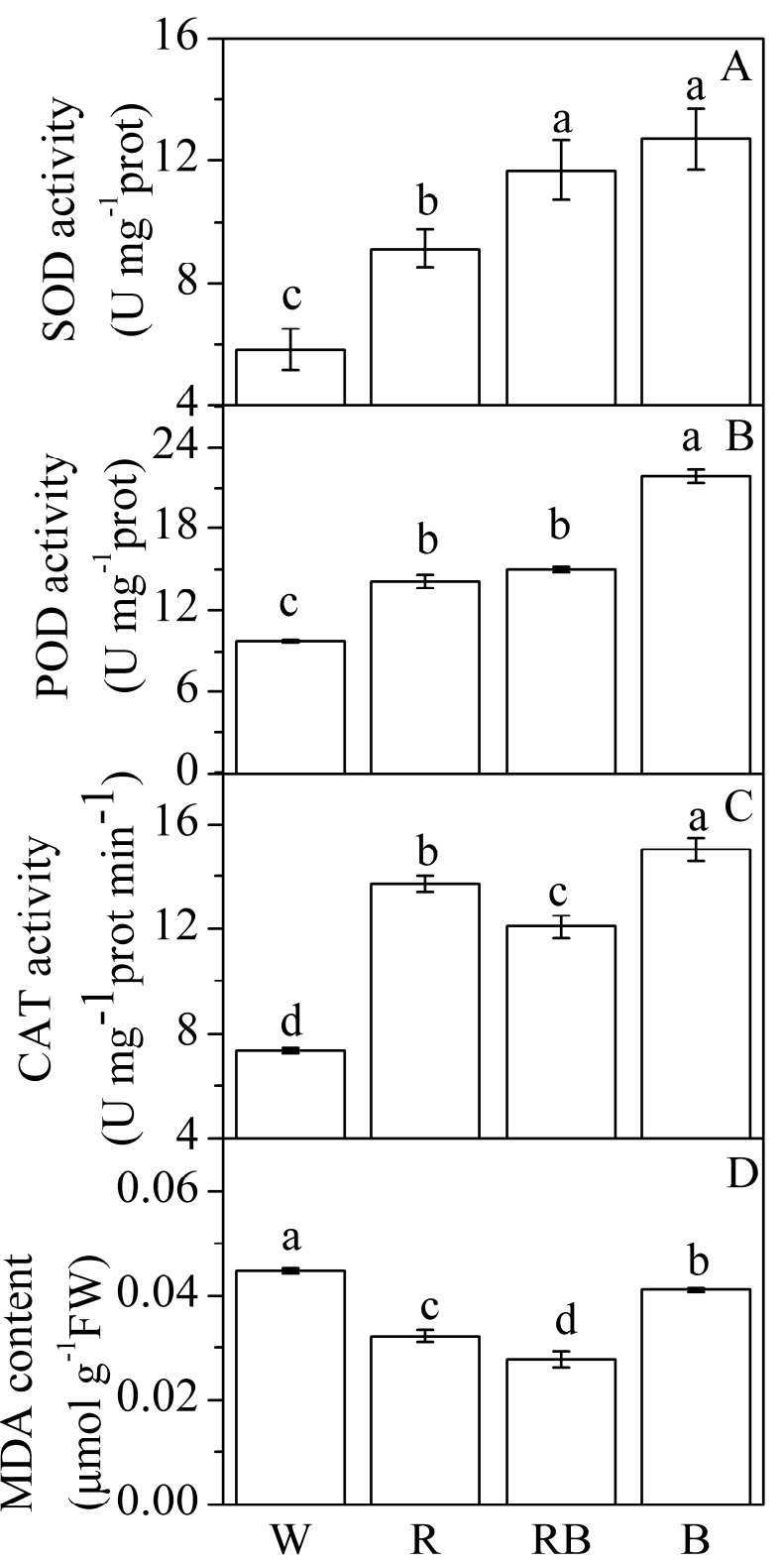

Fig. 3. Effects of light quality on activity of superoxide dismutase (SOD) (A), peroxidase (POD) (B) and catalase (C) and malondialdehyde (MDA) (D) content for fruiting mulberry leaves. W, white light; R, red light; RB, a mixture of red and blue light (red LED : blue LED = 5:1); B, blue light. Different letters indicate significant differences at the level of $5 \%$ (LSD test, $\mathrm{p}<0.05)$. The values represent means \pm SE $(\mathrm{n}=$ 3) 

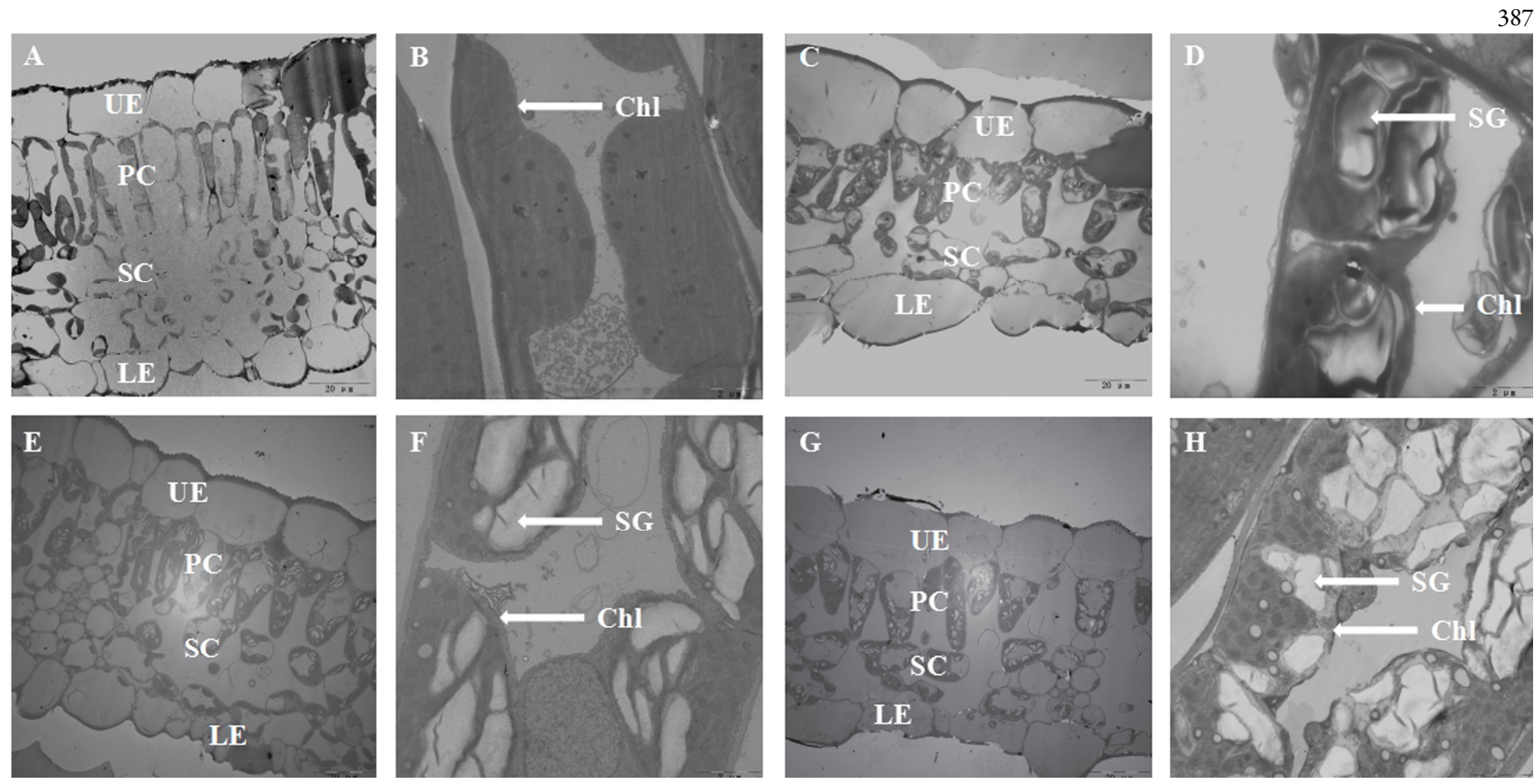

Fig. 5. Transmission electron micrographs of leaf cross sections and chloroplast ultrastructures in fruiting mulberry leaves grown under white light $(\mathrm{A}, \mathrm{B})$, red light $(\mathrm{C}, \mathrm{D})$, a mixture of red and blue light (red LED : blue LED = 5: 1) (E, F) and blue light (G, H). Scale bars are 20 and $2 \mu \mathrm{m}$. UE, upper epidermal cell; LE, lower epidermal cell; PC, palisade mesophyll cell; SC, spongy mesophyll cell; Chl, chloroplast; SG, starch granules

Different light qualities significantly influenced the anatomical structure of leaf cross sections (Fig. 5, Table 3). Under W, the palisade mesophyll cells arranged tightly with regular-shaped chloroplasts and absence of starch granules in the chloroplasts (Fig. 5A, 5B). This may be because leaf samples for transmission electron microscopy (TEM) observation were taken at the beginning of the photoperiod. In addition, leaf thickness, palisade tissue length and spongy tissue length under $\mathrm{W}$ were the largest (Table 3 ). However, the arrangement of palisade mesophyll cells under $\mathrm{RB}$ and $\mathrm{B}$ was relatively loose (Fig. 5E, 5G). Leaf thickness, palisade tissue length and spongy tissue length in plants grown under $\mathrm{B}$ and $\mathrm{RB}$ were slightly lower than those under W (Table 3). Under R, palisade mesophyll cells arranged most loosely (Fig. 5C), leaf thickness, palisade tissue length and spongy tissue length were the shortest (Table 3). There was a relatively larger number of starch granules in the chloroplasts under R, B and RB (Fig. 5D, 5F and $5 \mathrm{H})$.

\section{Discussion}

Light quality has a significant influence on the growth and morphogenesis of plants. Our results showed that R promoted the increase of stem length and leaf area, while a high proportion of $\mathrm{B}$ inhibited stem elongation and leaf expansion (Table 1). Dougher and Bugbee (2001) studied the response curves of leaf area and stem length of soybean plants (Glycine $\max \mathrm{L}$.) to blue light dose, indicating that the leaf area and stem length of soybean plants decreased with the increased proportion of blue light. Studies have also shown that blue light can inhibit internode growth and cell division of many plant species (Appelgren et al., 2003; Folta et al., 2003; Dougher and Bugbee, 2004). Our results were similar to these reports (Table 1). Goins et al. (1997) found that the dry matter of wheat
Table 3. Effects of light quality on leaf anatomical structure of fruiting mulberry leaves

\begin{tabular}{cccc}
\hline $\begin{array}{c}\text { Light } \\
\text { treatments }\end{array}$ & $\begin{array}{c}\text { Leaf thickness } \\
(\mu \mathrm{m})\end{array}$ & $\begin{array}{c}\text { Palisade tissue } \\
\text { length }(\mu \mathrm{m})\end{array}$ & $\begin{array}{c}\text { Spongy tissue } \\
\text { length }(\mu \mathrm{m})\end{array}$ \\
\hline $\mathrm{W}$ & $92.67 \pm 1.53 \mathrm{a}$ & $31.17 \pm 0.76 \mathrm{a}$ & $36.67 \pm 2.08 \mathrm{a}$ \\
$\mathrm{R}$ & $75.83 \pm 1.89 \mathrm{c}$ & $22.13 \pm 1.21 \mathrm{~d}$ & $18.03 \pm 1.95 \mathrm{c}$ \\
$\mathrm{RB}$ & $81.00 \pm 1.00 \mathrm{~b}$ & $28.53 \pm 1.50 \mathrm{~b}$ & $19.33 \pm 2.08 \mathrm{c}$ \\
$\mathrm{B}$ & $90.73 \pm 2.05 \mathrm{a}$ & $25.20 \pm 1.06 \mathrm{c}$ & $31.07 \pm 1.01 \mathrm{~b}$ \\
\hline
\end{tabular}

Note: Different letters within a column indicate significant differences at the level of $5 \%$ (LSD test, $p<0.05)$. The values represent means \pm SE $(n=5)$. W, white light; R, red light; $R B$, a mixture of red and blue light (red LED : blue $L E D=5$ : 1); B, blue light

plants (Triticum aestivum L.) grown under red light was lower than those grown under white fluorescent lamps or under a mixture of red and blue light. Meanwhile, Sebastian and Prasad (2014) reported that the dry biomass of rice plants under blue LEDs was lower than rice plants under white LEDs, but significantly higher than rice plants under red LEDs. The biomass of upland cotton (Gossypium hirsutum L.) plantlets in vitro under a certain proportion of red and blue LEDs was higher than upland cotton plantlets under white fluorescent lamps, red LEDs or blue LEDs alone (Li and Tang, 2010). The dry mass of orchid (Oncidium) plantlets grown under red LEDs supplemented with blue light was higher than that of white fluorescent tubes-grown plantlets (Liu et al., 2011). Lettuce plants (Lactuca sativa L.) had a lower dry mass under a mixture of red and blue LEDs compared with white fluorescent lamps (Stutte, 2009). Our results showed that although the dry weights (DW) of leaves and stems grown under RB were significantly lower than leaves and stems grown under $\mathrm{W}$, it was higher than leaves and stems grown under $\mathrm{R}$ and $B$ (Table 1). A previous study showed that the lack of blue 

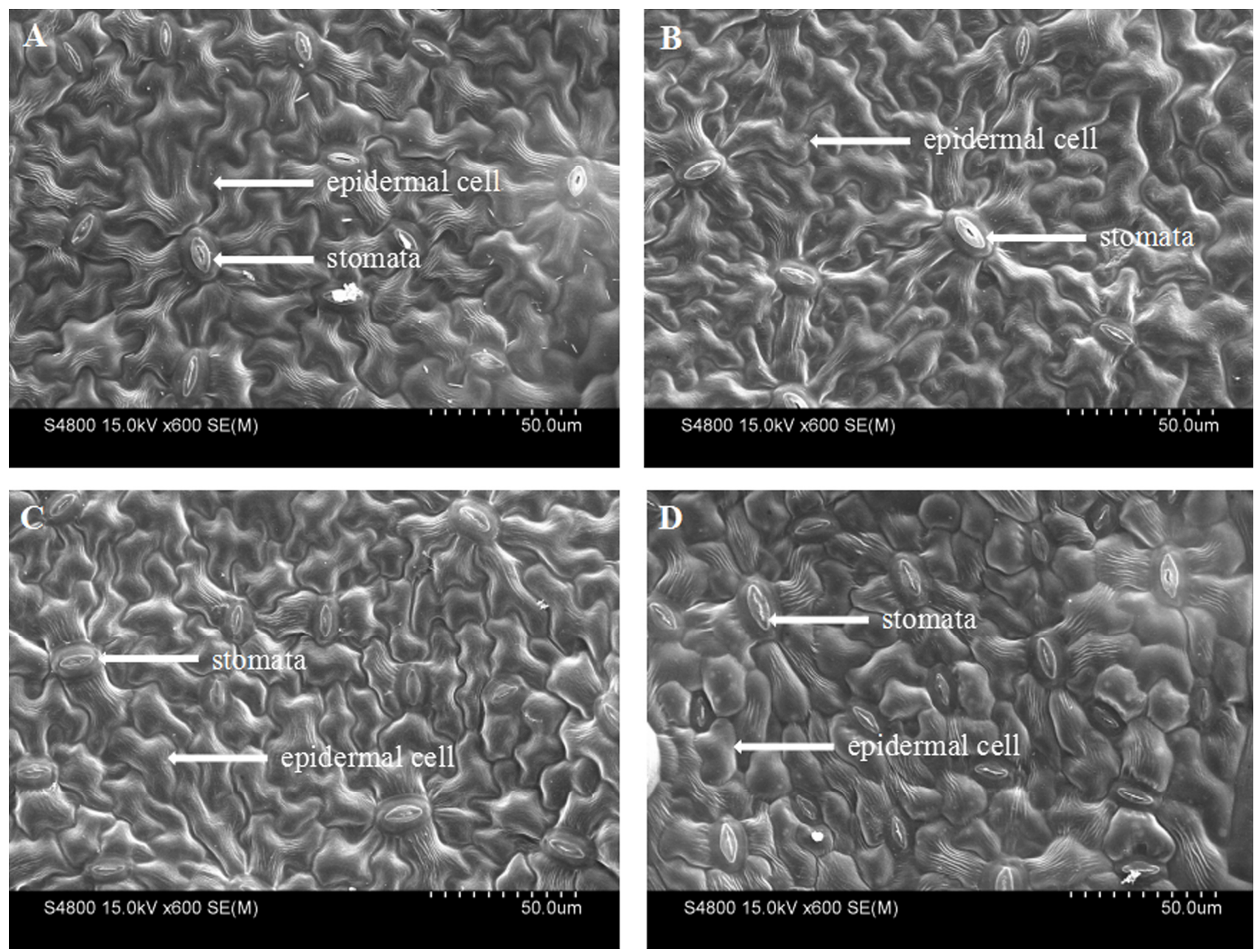

Fig. 4. Scanning electron micrographs of abaxial surfaces of fruiting mulberry leaves grown under white light (A), red light (B), a mixture of red and blue light (red LED : blue LED = 5:1) (C) and blue light (D). The scale bar is $50 \mu \mathrm{m}$

light can result in the reduction of LMA in soybean leaves (Britz and Sager, 1990), and LMA of cucumber seedlings (Cucumis sativus L.) grown under red light was the lowest and it increased with an elevated proportion of blue light, yet decreased to some extent under monochromatic blue light (Hogewoning et al., 2010b). Our results were not entirely consistent with these reports, although LMA of plants grown under $\mathrm{R}$ was the lowest, while LMA under $\mathrm{B}$ was significantly higher than other light quality treatments (Table 1). Leaf responses to the high proportion of blue light are similar to leaf responses to high light intensity (Hogewoning et al., 2010b). The increase of LMA is a common plant response to high light intensity. Thus, plants grown under $\mathrm{RB}$ and $\mathrm{B}$ responded as though they were being grown under high light even though plants were grown under a low light intensity of $100 \mu \mathrm{mol} \mathrm{m} \mathrm{m}^{-2}$ ${ }^{1}$ in the present study. These results also indicated that light quality can affect plant growth; however, the responses of plants to light quality may be species dependent.

Several studies showed that the Pn of plants grown under red light was lower than that of plants grown under white fluorescent light or a mixture of red and blue light (Goins et al., 1997; Yorio et al., 2001; Matsuda et al., 2004). Plants grown under blue light showed similar photosynthesis to those adapted to high light conditions (Matsuda et al., 2008). A relatively higher proportion of blue light can cause leaves to present so-called "sun type" characteristics and these leaves had high LMA and photosynthetic capacity (Matsuda et al., 2004; Matsuda et al., 2008; Hogewoning et al., 2010b). In this study, we found that the $\mathrm{Pn}$ of leaves grown under $\mathrm{RB}$ was higher than that of leaves grown under $\mathrm{R}$ and $\mathrm{B}$, but had no significant difference compared with leaves grown under W (Fig. 1A). Compared with plants grown under a mixture of red and blue light, the relatively lower chlorophyll content of the plants under blue light resulted in the decrease of $\mathrm{Pn}$ (Hogewoning $e t$ al., 2010b; Savvides and Fanourakis, 2012). In this study, there was no significant difference among chlorophyll contents under $\mathrm{B}, \mathrm{W}$ and RB. Hence, the lower Pn of plants under $\mathrm{B}$ had no correlation with chlorophyll content (Table 2). Both blue light and red light can induce stomatal opening (Briggs and Huala, 1999). Compared with monochromatic blue light or mixtures of red and blue light, the gs in cucumber leaves under red light decreased significantly (Savvides and Fanourakis, 2012). The gs of Rosa hybrida, Chrysanthemum morifolium and Campanula portenschlagiana plants increased with increments of the blue to red light ratio (Ouzounis et al., 2014). Several studies have shown that gs of plants grown 
under blue light was higher than gs of plants grown under other monochromatic lights (Wang et al., 2009; O'Carrigan et al., 2014; Wang et al., 2015). In the present study, gs of plants grown under $\mathrm{B}$ was significantly higher than other light quality treatments, but Pn of plants grown under B was significantly lower than those grown under W (Fig. 1). Therefore, the availability of $\mathrm{CO}_{2}$ did not restrict the photosynthesis of plants grown under $\mathrm{B}$. The unbalanced allocation of excitation energy between photosystem I and photosystem II resulted in the reduction of Pn under monochromatic lights (Goins et al., 1997; Kim et al., 2006). Our observation of a dramatic decrease in the actual photochemical efficiency of PSII (ФPSII) under R and $\mathrm{B}$ was in line with these results (Fig. 2B). However, other factors may also result in the decrease of Pn under $\mathrm{R}$. In this study, the gs, chlorophyll content, soluble protein content, and total leaf $\mathrm{N}$ content of leaves under $\mathrm{R}$ decreased significantly (Fig. 1B, Table 2). As Rubisco is the main constituent of soluble protein, the Rubisco content under R may significantly decrease. Photosynthesis is also dependent on total leaf $\mathrm{N}$ content (Hikosaka and Terashima, 1995); hence, in addition to the reduced $\Phi$ PSII under $\mathrm{R}$, inhibition of $\mathrm{CO}_{2}$ carboxylation may also be a reason for the reduction of $\mathrm{Pn}$ under R compared with RB and B treatments. The gs, ФPSII, soluble protein content and chlorophyll content of plants grown under RB had no significant difference compared with plants grown under W (Fig. 1B, 2B and Table 2). This is a possible reason for why there was no significant difference in Pn between plants under W and RB. This result was consistent with the report that $\mathrm{Pn}$ of rice plants grown under a mixture of red and blue light was higher than rice plants grown under red light alone due to the higher Rubisco and total leaf $\mathrm{N}$ content in plants grown under a mixture of red and blue light (Matsuda et al., 2004). Wang et al. reported that the decrease of ФPSII of plants under monochromatic red or blue light was caused by the decreased $\mathrm{qP}$ and $\mathrm{Fv}^{\prime} / \mathrm{Fm}^{\prime}$ (Wang et al., 2009). Hogewoning et al. (2010b) found that Fv/Fm and DPSII of plants grown under blue light and combinations of red and blue light were significantly higher than those grown under red light, yet $\mathrm{Fv} / \mathrm{Fm}$ and $\Phi$ PSII of plants had no significant difference between blue light and combinations of red and blue light, and in addition, monochromatic red light resulted in dysfunctional photosynthetic machinery. Ouzounis et al. (2015) also reported that the $\mathrm{Fv} / \mathrm{Fm}$ of phalaenopsis sp. grown under red light alone was significantly lower than the Fv/Fm of plants grown under a mixture of red and blue light. Our results were similar to these findings (Fig. 2A, 2B and 2C). This study also found that compared with fruiting mulberry plants grown under W, the NPQ of plants grown under $B$ or R increased significantly, while the NPQ of plants grown under RB increased slightly (Fig. 2D), indicating that the dysfunctional photosynthetic machinery of plants under monochromatic $\mathrm{R}$ or $\mathrm{B}$ resulted in the increasing proportion of excitation energy captured by photosystem II, which was dissipated in the form of NPQ.

The production of pigments and carbohydrates in leaves of plant is influenced by light environment (Wang et al., 2009; Li and Tang, 2010; Terfa et al., 2013). Light is an important factor for the production of pigments and exposure to different light qualities triggers different physiological responses (Ouzounis et al., 2015). In this study, we found that light quality affected the chlorophyll $\mathrm{a} / \mathrm{b}$ ratio and carbohydrate content (Table 2). The chlorophyll a/b ratio of plants grown under $\mathrm{R}$ was significantly lower than that of plants grown under $\mathrm{RB}$ and $\mathrm{B}$ (Table 2). This is consistent with the effect of light quality on the chlorophyll $\mathrm{a} / \mathrm{b}$ ratio in cucumber leaves (Hogewoning et al., 2010b). Several studies suggested that red light inhibited the formation of chlorophyll because 5aminolevulinic acid, a biosynthetic precursor to chlorophyll, was reduced under red light (Tanaka et al., 1998; Sood et al., 2005). Blue light was reported to play a crucial role in the formation and accumulation of chlorophylls (Dougher and Bugbee, 1997; Li et al., 2012; Fan et al., 2013). Therefore, in this study, the higher chlorophyll content and chlorophyll a/b ratio under $\mathrm{RB}$ and $\mathrm{B}$ may have resulted from the effect of blue light on chlorophyll biosynthesis. The higher chlorophyll a/b ratio indicated lower chlorophyll b content in the photosynthetic apparatus, demonstrating adaptation to high light and a stronger ability of light energy conversion (Evans, 1988). In the present study, sucrose content and starch content of leaves grown under $\mathrm{W}$ and $\mathrm{R}$ were significantly lower than in leaves grown under $\mathrm{RB}$ and $\mathrm{B}$ (Table 2). Obviously, the inhibition effect of feedback control on photosynthesis cannot be ruled out under R, B and RB (Stitt, 1991).

A recent study showed that compared with white light, the antioxidant enzymes activity in rice leaves under monochromatic red or blue light increased significantly, while the MDA content decreased significantly (Sebastian and Prasad, 2014). Additionally, Dong et al. (2014) found that compared with white light, red light and a mixture of red and blue light could enhance the SOD activity of wheat leaves during flowering. Our results showed that the SOD, POD and CAT activities of leaves grown under R, RB and B increased significantly compared with those of leaves grown under $\mathrm{W}$ (Fig. 3A, 3B and 3C). This may result from the more effective absorption of chlorophylls to red and blue light, thus resulting in saturation of the photosynthetic electron transport chain and ultimate enhancement of the antioxidant activity (Wu et al., 2003). Superoxide dismutase (SOD), POD and CAT are components of the plant reactive oxygen defense system. This system plays an important role in preventing or reducing the damage of reactive oxygen species (ROS) (Logan et al., 2006). Therefore, higher activities of SOD, POD and CAT may effectively scavenge the ROS and alleviate the damage of ROS to the membrane lipid of the cell. Hence, in this study, the lipid peroxidation product of MDA content under R, RB and $B$ were significantly lower than in plants grown under W (Fig. 3D).

A previous study indicated that the stomatal density of plants grown under red light was significantly lower than that of plants grown under blue light and white light (Wang et al., 2009). It was also reported that with an increasing proportion of blue light, the stomatal density of plants grown under a mixture of red and blue light increased gradually (Hogewoning et al., 2010b). However, Li et al. (2010) found that the stomatal density of upland cotton plantlets grown under red LEDs was higher than that of plantlets grown under white fluorescent lamps, mixtures of red and blue LEDs, or blue LEDs. In this study, we found that the number of stomata distributed in leaves grown under $\mathrm{B}$ was the greatest, the number of stomata in leaves grown under $\mathrm{W}$ and $\mathrm{RB}$ was almost the same, and the number of stomata of leaves grown under $\mathrm{R}$ was the least (Fig. 4). The distribution, number per unit epidermis area of 
390

stomata in the leaves greatly influence photosynthesis, gs, and the other physiological activities (Liu et al., 2011). Therefore, the higher gs under B may be partly due to a higher number of stomata in leaves (Fig. 4D). We also found that the morphology of leaf epidermal cells under B was different than in fruiting mulberry plants grown under other light quality treatments (Fig. 4D). Light quality also had an impact on leaf anatomy (Macedo et al., 2011; Wu et al., 2014). Our research showed that plants grown under $\mathrm{R}$ had the thinnest leaves, which might be caused by the decreased length of palisade and spongy tissue (Fig. 5C, Table 3). Compared with plants grown under $\mathrm{R}$, the leaves were thicker, the palisade tissue and spongy tissue were longer under $\mathrm{RB}$ or $\mathrm{B}$ treatments (Table 3 ). This was consistent with the results of previous studies that found that leaf thickness and palisade tissue length of plants decreased under lower levels of blue light (Li and Tang, 2010; Terfa et al., 2013). The palisade tissue length also showed a tendency similar to the activity of Pn (Table 3, Fig. 1A). In short, the enhancement of the leaf thickness and Pn resulting from blue light seems to be concerned with the well-developed structure of palisade tissue cells in fruiting mulberry leaves.

\section{Conclusions}

This study showed that $\mathrm{R}$ promoted stem elongation and leaf expansion, reduced LMA, total leaf $\mathrm{N}$ content, and gs. Blue light (B) inhibited stem elongation and leaf expansion, increased LMA, total leaf $\mathrm{N}$ content, and gs. The decrease of Pn under B was mainly attributed to the inactivation of the photosystem, and the decrease of Pn under R was also affected by the decrease of chlorophyll, soluble protein content and gs. The growth performance and physiological characteristics of plants grown under $\mathrm{RB}$ were similar to those of plants grown under W. The results of this study showed that a certain ratio of mixed red and blue LEDs light could reduce the adverse effects of monochromatic red or blue LEDs light on fruiting mulberry plants. Monochromatic red and blue light may play their own roles in metabolism and development of plants; however, their effects were relatively limited compared with broad-spectrum light (W). Thus, the mixture of red and blue LEDs light may be more beneficial for plant growth and development. Future research is proposed to analyze plant physiological responses to different ratios of blue and red light at higher PPFD.

\section{Acknowledgements}

This work was supported by the Fundamental Research Funds for the Central Universities (grant number 2572015AA27).

\section{References}

Aebi H (1984). Catalase in vitro. Methods in Enzymology 105:121-126. Ahmad M, Grancher N, Heil M, Black RC, Giovani B, Galland P, Lardemer D (2002). Action spectrum for cryptochrome-dependent hypocotyl growth inhibition in Arabidopsis. Plant Physiology 129(2):774-785.

Appelgren M (1991). Effects of light quality on stem elongation of Pelargonium in vitro. Scientia Horticulturae 45(3):345-351.
Appelgren H, Kniola B, Ekwall K (2003). Distinct centromere domain structures with separate functions demonstrated in live fission yeast cells. Journal of Cell Science 116(19):4035-4042.

Arnon DI (1949). Copper enzymes in isolated chloroplasts. Polyphenoloxidase in Beta vulgaris. Plant Physiology 24(1):1-15.

Bradford MM (1976). A rapid and sensitive method for the quantitation of microgram quantities of protein utilizing the principle of protein-dye binding. Analytical Biochemistry 72(12):248-254.

Briggs WR, Huala E (1999). Blue-light photoreceptors in higher plants. Annual Review of Cell and Developmental Biology 15(1):33-62.

Britz SJ, Sager JC (1990). Photomorphogenesis and photoassimilation in soybean and sorghum grown under broad spectrum or bluedeficient light sources. Plant Physiology 94(2):448-454.

Brown CS, Schuerger AC, Sager JC (1995). Growth and photomorphogenesis of pepper plants under red light-emitting diodes with supplemental blue or far-red lighting. Journal of the American Society for Horticultural Science 120(5):808-813.

Buysse J, Merckx R (1993). An improved colorimetric method to quantify sugar content of plant tissue. Journal of Experimental Botany 44:1627-1629.

Chen M, Chory J, Fankhauser C (2004). Light signal transduction in higher plants. Annual Review of Genetics 38:87-117.

Demotes-Mainard S, Péron T, Corot A, Bertheloot J, Le Gourrierec J, Pelleschi-Travier S, ... Vian A (2016). Plant responses to red and far-red lights, applications in horticulture. Environmental and Experimental Botany 121:4-21.

Dong C, Fu Y, Liu G, Lu H (2014). Growth, photosynthetic characteristics, antioxidant capacity and biomass yield and quality of wheat (Triticum aestivum L.) exposed to LED light sources with different spectra combinations. Journal of Agronomy and Crop Science 200(3):219-230.

Dougher TAO, Bugbee BG (1997). Is blue light good or bad for plants? Life Support \& Biosphere Science International Journal of Earth Space 5(2):129-136.

Dougher TAO, Bugbee BG (2001). Differences in the response of wheat, soybean and lettuce to reduced blue radiation. Photochemistry Photobiology 73(2):199-207.

Dougher TAO, Bugbee BG (2004). Long-term blue light effects on the histology of lettuce and soybean leaves and stems. Journal of the American Society Horticultural Science 129(4):467-472.

Ercisli S, Orhan E (2007). Chemical composition of white (Morus alba), red (Morus rubra) and black (Morus nigra) mulberry fruits. Food Chemistry 103(4):1380-1384.

Eskins K, Jiang CZ, Shibles R(1991). Light quality and irradiance effects on pigments, light-harvesting proteins and Rubisco activity in a chlorophyll- and light-harvesting-deficient soybean mutant. Physiologia Plantarum 83(1):47-53.

Evans JR (1988). Acclimation by the thylakoid membranes to growth irradiance and the partitioning of nitrogen between soluble and thylakoid proteins. Functional Plant Biology 15(2):93-106.

Fankhauser C, Chory J (1997). Light control of plant development. Annual Review of Cell and Developmental Biology 13(1):203-229. 
Fan XX, Zang J, Xu ZG, Guo SR, Jiao XL, Liu XY, Gao Y (2013). Effects of different light quality on growth, chlorophyll concentration and chlorophyll biosynthesis precursors of nonheading Chinese cabbage (Brassica campestris L.). Acta Physiologiae Plantarum 35(9):2721-2726.

Folta KM, Lieg EJ, Durham T, Spalding EP (2003). Primary inhibition of hypocotyl growth and phototropism depend differently on phototropin-mediated increases in cytoplasmic calcium induced by blue light. Plant Physiology 133(4):1464-1470.

Folta KM, Pontin MA, Karlin-Neumann G, Bottini R, Spalding EP (2003). Genomic and physiological studies of early cryptochrome 1 action demonstrate roles for auxin and gibberellin in the control of hypocotyl growth by blue light. Plant Journal 36(2):203-214.

Fukuda N, Ishii Y, Ezura H, Olsen JE (2009). Effects of light quality under red and blue light emitting diodes on growth and expression of FBP28 in petunia. International Symposium on Light in Horticulture 907:361-366.

Giannopolitis CN, Ries SK (1977). Superoxide dismutases I. Occurrence in higher plants. Plant Physiology 59(2):309-314.

Goins GD, Yorio NC, Sanwo MM, Brown CS (1997). Photomorphogenesis, photosynthesis, and seed yield of wheat plants grown under red light-emitting diodes (LEDs) with and without supplemental blue lighting. Journal of Experimental Botany 48(7):1407-1413.

Hernández R, Kubota C (2016). Physiological responses of cucumber seedlings under different blue and red photon flux ratios using LEDs. Environmental and Experimental Botany 121:66-74.

Hikosaka K, Terashima I (1995). A model of the acclimation of photosynthesis in the leaves of $\mathrm{C} 3$ plants to sun and shade with respect to nitrogen use. Plant, Cell \& Environment 18(6):605-618.

Hogewoning SW, Harbinson J (2006). Plant physiological acclimation to irradiation by light-emitting diodes (LEDs)-implications for use in protected plant cultivation systems. Book of abstracts-27th International Horticultural Congress \& Exhibition, Seoul, Korea, 13-19 August 2006. (27):SO6011168-168.

Hogewoning SW, Douwstra P, Trouwborst G, Van leperen W, Harbinson J (2010). An artificial solar spectrum substantially alters plant development compared with usual climate room irradiance spectra. Journal of Experimental Botany 61(5):1267-76.

Hogewoning SW, Trouwborst G, Maljaars H, Poorter H, Van Ieperen W, Harbinson J (2010). Blue light dose-responses of leaf photosynthesis, morphology, and chemical composition of Cucumis sativus grown under different combinations of red and blue light. Journal of Experimental Botany 61(11):3107-3117.

Huché-Thélier L, Crespel L, Le Gourrierec J, Morel P, Sakr S, Leduc N (2016). Light signaling and plant responses to blue and UV radiations-Perspectives for applications in horticulture. Environmental and Experimental Botany 121:22-38.

Inada K (1976). Action spectra for photosynthesis in higher plants. Plant Cell and Physiology 17(2):355-365.

Johkan M, Shoji K, Goto F, Hashida S, Yoshihara T (2010). Blue lightemitting diode light irradiation of seedlings improves seedling quality and growth after transplanting in red leaf lettuce. HortScience 45(12):1809-1814.
Kim HH, Wheeler RM, Sager JC (2007). Electric lighting considerations for crop production in space. Acta Horticulturae 761(761):193-202.

Li H, Xu Z, Tang C (2010). Effect of light-emitting diodes on growth and morphogenesis of upland cotton (Gossypium hirsutum L.) plantlets in vitro. Plant Cell, Tissue and Organ Culture 103(2):155163.

Li H, Tang C, Xu Z, Liu X, Han X (2012). Effects of different light sources on the growth of non-heading Chinese cabbage (Brassica campestris L.). Journal of Agricultural Science 4(4):262.

Liu MX, Xu ZG, Yang Y, Feng YJ (2011). Effects of different spectral lights on Oncidium PLBs induction, proliferation, and plant regeneration. Plant Cell, Tissue and Organ Culture 106(1):1-10.

Liu XY, Guo SR, Xu ZG, Jiao XL, Tezuka T (2011). Regulation of chloroplast ultrastructure, cross-section anatomy of leaves, and morphology of stomata of cherry tomato by different light irradiations of light-emitting diodes. HortScience 46(2):217-221.

Logan BA, Kornyeyev D, Hardison J, Holaday AS (2006). The role of antioxidant enzymes in photoprotection. Photosynthesis Research 88(2):119-132.

Macedo AF, Leal-Costa MV, Tavares ES, Lage CLS, Esquibel MA (2011). The effect of light quality on leaf production and development of in vitro-cultured plants of Alternanthera brasiliana Kuntze. Environmental and Experimental Botany 70(1):43-50.

Maehly PC, Chance M (1954). The assay of catalase and peroxidases. In: D Gluck, ed, Methods of biochemical analysis. Interscience Publishers, New York, pp 357-424.

Martin AB, Cuadrado Y, Guerra H, Gallego P, Hita O, Martine L, .. . Villalobos N (2000). Differences in the contents of total sugars, reducing sugars, starch and sucrose in embryogenic and nonembrogenic calli from Medicago arborea L. Plant Science 154:143-151.

Massa GD, Emmerich JC, Morrow RC, Bourget M, Mitchell CA (2007). Plant-growth lighting for space life support: a review. Gravitational \& Space Research 19(2):19-30.

Massa GD, Kim HH, Wheeler RM, Mitchell CA (2008). Plant productivity in response to LED lighting. HortScience 43(7):19511956.

Matsuda R, Ohashi-Kaneko K, Fujiwara K, Goto E, Kurata K (2004). Photosynthetic characteristics of rice leaves grown under red light with or without supplemental blue light. Plant and Cell Physiology 45(12):1870-1874.

Matsuda R, Ohashi-Kaneko K, Fujiwara K, Kurata K (2008). Effects of blue light deficiency on acclimation of light energy partitioning in PSII and $\mathrm{CO}_{2}$ assimilation capacity to high irradiance in spinach leaves. Plant and Cell Physiology 49(4):664-670.

Milivojević DB, Tyszkiewicz E (1992). Effect of light quality on the organization of chloroplast thylakoids of Pinus nigra Arn. Plant Physiology 139(5):574-578.

O'Carrigan A, Babla M, Wang F, Liu X, Mak M, Thomas R, ... Chen $\mathrm{ZH}$ (2014). Analysis of gas exchange, stomatal behaviour and micronutrients uncovers dynamic response and adaptation of tomato plants to monochromatic light treatments. Plant Physiology and Biochemistry 82:105-115. 
392

Ouzounis T, Fretté X, Rosenqvist E, Ottosen CO (2014). Spectral effects of supplementary lighting on the secondary metabolites in roses, chrysanthemums, and campanulas. Journal of Plant Physiology 171(16):1491-1499.

Ouzounis T, Fretté X, Ottosen CO, Rosenqvist E (2015). Spectral effects of LEDs on chlorophyll fluorescence and pigmentation in Phalaenopsis 'Vivien' and 'Purple Star'. Physiologia Plantarum 154(2):314-327.

Park SY, Kim MJ (2010). Development of zygotic embryos and seedlings is affected by radiation spectral compositions from light emitting diode (LED) system in Chestnut (Castanea crenata S. et Z.). Journal the Korean Society 99:750-754.

Savvides A, Fanourakis D, Van Ieperen W (2012). Co-ordination of hydraulic and stomatal conductances across light qualities in cucumber leaves. Journal of Experimental Botany 63(3):1135-1143.

Sebastian A, Prasad MNV (2014). Red and blue lights induced oxidative stress tolerance promote cadmium rhizocomplexation in Oryza sativa. Journal of Photochemistry \& Photobiology B: Biology 137:135-143.

Sood S, Gupta V, Tripathy BC (2005). Photoregulation of the greening process of wheat seedlings grown in red light. Plant Molecular Biology 59(2):269-287.

Stewart RRC, Bewley JD. Lipid peroxidation associated with accelerated aging of soybean axes. Plant Physiology 65(2):245-248.

Stitt M (1991). Rising $\mathrm{CO}_{2}$ levels and their potential significance for carbon flow in photosynthetic cells. Plant, Cell \& Environment 14(8):741-762.

Stutte GW (2009). Light-emitting diodes for manipulating the phytochrome apparatus. HortScience 44(2):231-234.

Tanaka M, Takamura T, Watanabe H, Endo M, Yanagi T, Okamato K (1998). In vitro growth of Cymbidium plantlets cultured under superbright red and blue light-emitting diodes (LEDs). Journal of Horticultural Science Biotechnology 73(1):39-44.
Terfa MT, Solhaug KA, Gislerød HR, Olsen JE, Torre S (2013). A high proportion of blue light increases the photosynthesis capacity and leaf formation rate of Rosa hybrida but does not affect time to flower opening. Physiologia Plantarum 148(1):146-159.

Wang H, Gu M, Cui J, Shi K, Zhou Y, Yu J (2009). Effects of light quality on $\mathrm{CO}_{2}$ assimilation, chlorophyll-fluorescence quenching, expression of Calvin cycle genes and carbohydrate accumulation in Cucumis sativus. Journal of Photochemistry and Photobiology B: Biology 96(1):30-37.

Wang XY, Xu XM, Cui J (2015). The importance of blue light for leaf area expansion, development of photosynthetic apparatus, and chloroplast ultrastructure of Cucumis sativus grown under weak light. Photosynthetica 53(2):213-222.

Wingler A, Marès M, Pourtau N (2004). Spatial patterns and metabolic regulation of photosynthetic parameters during leaf senescence. New Phytologist 161(3):781-789.

Wu MC, Hou CY, Jiang CM, Wang YT, Wang CY, Chen HH, Chang HM (2007). A novel approach of LED light radiation improves the antioxidant activity of pea seedlings. Food Chemistry 101(4):1753-1758.

Wu Q, Su N, Shen W, Cui J (2014). Analyzing photosynthetic activity and growth of Solanum lycopersicum seedlings exposed to different light qualities. Acta Physiologiae Plantarum 36(6):1411-1420.

Yorio NC, Goins GD, Kagie HR, Wheeler RM, Sager JC (2001). Improving spinach, radish, and lettuce growth under red lightemitting diodes (LEDs) with blue light supplementation. HortScience 36(2):380-383.

Zeiger E (1990). Light perception in guard cells. Plant, Cell \& Environment 13(7):739-744.

Zeiger E, Talbott LD, Frechilla S, Srivastava A, Zhu J (2002). The guard cell chloroplast: a perspective for the twenty-first century. New Phytologist 153(3):415-424. 